\title{
Inflammation-Mediated Regulation of MicroRNA Expression in Transplanted Pancreatic Islets
}

\author{
Valia Bravo-Egana, ${ }^{1}$ Samuel Rosero, ${ }^{1}$ Dagmar Klein, ${ }^{1}$ Zhijie Jiang, ${ }^{2}$ Nancy Vargas, ${ }^{1}$ \\ Nicholas Tsinoremas, ${ }^{2,3}$ Marco Doni, ${ }^{1,4,5}$ Michele Podetta, ${ }^{1,4,5}$ Camillo Ricordi, 1, 3, 6, 7,8 \\ R. Damaris Molano, ${ }^{1}$ Antonello Pileggi, ${ }^{1,6,7,8}$ and Ricardo L. Pastori ${ }^{1,3}$ \\ ${ }^{1}$ Diabetes Research Institute, University of Miami, Miami, FL, USA \\ ${ }^{2}$ Center for Computational Science, University of Miami, Miami, FL, USA \\ ${ }^{3}$ DeWitt Daughtry Department of Surgery, University of Miami Leonard M. Miller School of Medicine, Miami, FL, USA \\ ${ }^{4}$ Department of Medicine, University of Miami Leonard M. Miller School of Medicine, Miami, FL, USA \\ ${ }^{5}$ Institute of Hepatopancreatic Surgery, Istituto di Ricovero e Cura a Carattere Scientifico, \\ Fondazione Policlinico San Matteo, Pavia, Italy \\ ${ }^{6}$ Department of Surgical Sciences, University of Pavia, Pavia, Italy \\ ${ }^{7}$ Department of Microbiology and Immunology, and Department of Medicine, \\ University of Miami Leonard M. Miller School of Medicine, Miami, FL, USA \\ ${ }^{8}$ Department of Biomedical Engineering, University of Miami, Miami, FL, USA
}

Correspondence should be addressed to Antonello Pileggi, apileggi@med.miami.edu and Ricardo L. Pastori, rpastori@med.miami.edu

Received 14 December 2011; Revised 9 February 2012; Accepted 20 February 2012

Academic Editor: Diego Cantarovich

Copyright (C) 2012 Valia Bravo-Egana et al. This is an open access article distributed under the Creative Commons Attribution License, which permits unrestricted use, distribution, and reproduction in any medium, provided the original work is properly cited.

Nonspecific inflammation in the transplant microenvironment results in $\beta$-cell dysfunction and death influencing negatively graft outcome. MicroRNA (miRNA) expression and gene target regulation in transplanted islets are not yet well characterized. We evaluated the impact of inflammation on miRNA expression in transplanted rat islets. Islets exposed in vitro to proinflammatory cytokines and explanted syngeneic islet grafts were evaluated by miRNA arrays. A subset of 26 islet miRNAs was affected by inflammation both in vivo and in vitro. Induction of miRNAs was dependent on NF- $\kappa \mathrm{B}$, a pathway linked with cytokine-mediated islet cell death. RT-PCR confirmed expression of 8 miRNAs. The association between these miRNAs and mRNA target-predicting algorithms in genome-wide RNA studies of $\beta$-cell inflammation identified 238 potential miRNA gene targets. Several genes were ontologically associated with regulation of insulin signaling and secretion, diabetes, and islet physiology. One of the most activated miRNAs was miR-21. Overexpression of miR-21 in insulin-secreting MIN6 cells downregulated endogenous expression of the tumor suppressor Pdcd 4 and of Pclo, a Ca ${ }^{2+}$ sensor protein involved in insulin secretion. Bioinformatics identified both as potential targets. The integrated analysis of miRNA and mRNA expression profiles revealed potential targets that may identify molecular targets for therapeutic interventions.

\section{Introduction}

Inflammation involves both the innate and adaptive immune systems following infection or injury. Deregulation of this process leads to chronic inflammation, generating a pathological response that favors destruction of the tissue involved [1]. Inflammation is the common denominator of several pathological conditions, including type 1 and type 2 diabetes. It also contributes to immune rejection in transplantation.

A plethora of proinflammatory mediators has been associated with toxicity and impairment of $\beta$-cell function [2], including cytokines [3-6], hyperglycemia, and hyperlipidemia [7-9]. Inflammation plays key roles in islet engraftment and survival after transplantation. During 
the early posttransplant period, islet cells are exposed to noxious stimuli, activation of macrophages, local secretion of chemokines, tissue factor induction, and formation of reactive oxygen species (ROS) due to hypoxic conditions, all causing an impairment of engraftment and function [10-12]. The nonspecific inflammation generated in the transplant microenvironment triggers adaptive immune responses, negatively influencing graft survival $[13,14]$.

Emerging evidence shows that small noncoding gene products, miRNAs, negatively regulate gene expression posttranscriptionally $[15,16]$. MiRNAs play a critical role in inflammatory diseases [17-19], in the vascular system [20] and diabetes [21-25]. In this study, we determined the expression signatures of miRNAs in islets exposed to proinflammatory conditions in vitro [2] or after transplantation. Locked Nucleic Acids-probe (LNA) MicroRNA hybridization arrays and significance analysis of microarray (SAM) identified miRNA subsets modulated by both experimental conditions. To identify genes that are directly targeted by these miRNAs, we performed bioinformatic analysis relating the miRNA expression profiles with genome-wide RNA (GWR) microarray studies focusing on inflammation of pancreatic $\beta$-cells $[26,27]$.

This approach may lead to the development of molecular therapies to alter expression of involved miRNAs and their specific targets, which may enhance preservation of $\beta$-cell function and survival after transplantation.

\section{Material and Methods}

2.1. Islet Isolation. Animal procedures were performed under protocols reviewed and approved by the University of Miami IACUC. Lewis rats (Harlan, Indianapolis, IN) of either sex were used as donors and recipients of islet cells. Islets were obtained by a mechanically enhanced enzymatic digestion using Liberase (Roche) followed by separation on discontinuous density gradients (Mediatech) [28]. After overnight culture at $37^{\circ} \mathrm{C}, 5 \% \mathrm{CO}_{2}$ in supplemented CMRL1066 medium (Gibco-Invitrogen), islet aliquots were prepared in non-treated tissue culture dishes for in vitro or transplantation experiments.

2.2. Islet Exposure to Inflammation In Vitro. After overnight culture, isolated islets were exposed in vitro to a proinflammatory cytokine cocktail [29]. Briefly, recombinant human cytokines utilized in combination were as follows: interleukin-1-beta (IL-1 $\beta ; 50 \mathrm{U} / \mathrm{mL}$ ), interferongamma (IFN- $\gamma ; 100 \mathrm{U} / \mathrm{mL}$ ), and tumor necrosis factor-alpha (TNF- $\alpha ; 2,000 \mathrm{U} / \mathrm{mL}$ ), all from R\&D Systems. Islets were exposed to the treatment for 6 and 18 hours. In selected experiments aimed at dissecting the role of NF- $\kappa \mathrm{B}$ pathway in cytokine-induced islet miRNA expression, islets were pretreated for 2 hours with the NF- $\kappa$ B inhibitor Bay11-7082 $(5 \mathrm{uM})$, which inactivates $\mathrm{I} \kappa \mathrm{B}-\alpha$ phosphorylation, and then cultured with the cytokine cocktail for additional 6 hours. Untreated islets cultured in parallel were used as controls. At the end of the incubation period, islets were collected in saline solution, and then stored in RNALater until processed for molecular arrays.
2.3. Islet Transplantation and Graft Recovery. Islet aliquots $(\sim 3,000$ IEQ each) were transplanted under the kidney capsule, as described [14]. After three days, islet grafts were collected by careful dissection from the renal subcapsular space and stored in RNALater for molecular arrays.

2.4. Overexpression of miR-21 in MIN6 Cells. The MIN6 cells were transfected with $200-400 \mathrm{nM}$ mimic miR-21 (Dharmacon) or 200-400 nM irrelevant control using transfection reagent "Dharmafect" following the manufactures instructions. Mimic transfected cells and their controls were cultured 48 hours, harvested and subjected to qRT-PCR.

2.5. LNA-Oligonucleotide-Probes-Based Hybridization Arrays. RNA was labeled (Hy3 or Hy5 fluorescent dye) using the miRCURY LNA Array Power labeling kit (Exiqon). The labeled RNA molecules were hybridized to the miRCURY LNA Array slides (Exiqon) that contain capture probes for 279 rat microRNA genes complementary to mature miRNAs, registered in miR-Base Release 9.2. After hybridization, the chips underwent image acquisition (Scanner Axon model 4100A; Molecular Devices) and the data analyzed using GenePix Pro 6.0 image analysis software. Replicate hybridizations of the same control/experimental samples were performed utilizing the two-color "dye flip reversal method." This experiment was repeated with 3 samples for a total of six hybridizations.

The averages of both hybridizations ( $\mathrm{Hy} 3 / \mathrm{Hy} 5$ and $\mathrm{Hy} 5 / \mathrm{Hy} 3)$ for three samples were analyzed by Significant Analysis of Microarray (SAM). Only miRNAs detected in both dye flip reversal were included in the analysis. SAM calculates $q$-values, a measure of significance based on False Discovery Rate concept for genome-wide association studies [30]. To increase the stringency of the analysis only samples with $q=0$ were considered.

2.6. Quantitative RT-PCR. Total RNA was isolated from transplanted islets using the mirVana miRNA Isolation kit (Ambion). The isolated RNA can be used for miRNA as well as mRNA analysis. cDNA synthesis and PCR amplification were performed according to the manufacturer's protocol (Applied Biosystems). MiRNA profiling was performed using micro-fluidic cards TaqMan Low Density Array (TLDA, v1.0) for rodent miRNAs, which allow quantitative assessment of 365 miRNAs using the AB7900 instrument (Applied Biosystems). Quantification of miR-21 and mRNA was carried out in a 7500 Fast Real-time PCR system, utilizing TaqMan reagents (Applied Biosystems) using (RQ) values. $\mathrm{RQ}$ represents the fold changes of expression between control and treated samples, for example, nontransplanted islets versus transplanted islets. RQs were calculated with the Applied Biosystems SDS software. The number of amplification cycles, $\mathrm{Ct}$, is normalized to endogenous control $18 \mathrm{~S}$ rRNA for the TLDA, and beta-actin and snoRNA135 for mRNA and miR-21 assessments, respectively.

2.7. Semiquantitative RT-PCR Analysis of Pclo Splicing Versions. PCR was performed using the following primers: Pclo 
forward primer sequence TCCAAGGATATGCAGGTTCC is shared by both versions (V1 and V2, resp.) and spans between exons 19 and 20. The reverse primers are specific for each version and are as follows: ACGCTATACCCACTGCCAAC (V1) and TGAACATTAAGCTGCCATGC (V2).

\section{Results}

3.1. MicroRNA Expression in Islets after In Vitro Treatment with Proinflammatory Cytokines. Inflammation can be mimicked in vitro by exposing islets to proinflammatory cytokines. Specifically, IL-1 $\beta$ induces functional impairment and cell death in cultured islets [31], while TNF- $\alpha$ and IFN- $\gamma$ enhance cytotoxicity [32]. The miRNA expression patterns in rat islets exposed to cytokine cocktail [IL- $1 \beta$ $(50 \mathrm{U} / \mathrm{mL}), \mathrm{TNF}-\alpha(2000 \mathrm{U} / \mathrm{mL})$, and IFN- $\gamma(100 \mathrm{U} / \mathrm{mL})$ ] for either 6 or 18 hours $(n=3)$ were assessed by LNA-(locked nucleic acids) based microarray analysis, using Exiqon chips. We chose the LNA probes because of their accurate sequence discrimination and strong hybridization [33]. They are comparable to the emergent next-generation sequencing (NGS) high throughput miRNA profiling via RNA sequencing [34].

The maximum cytokine effect on miRNA profiles occurred 6 hours after treatment, while after 18 hours the effect was markedly reduced (data not shown). The results obtained from the miRNA microarrays $(n=3)$ were analyzed by SAM [30], adopting a $q=0$. Q-values correspond to the $P$ values adapted to the analysis of a large number of genes; $q=0$ is the minimum false discovery rate and refers to the chance that a given miRNA is a false positive (fold changes greater than 2.0). We identified a pool of 64 miRNAs (Table 1). The NF- $\kappa$ B pathway has a critical role in cytokine-induced islet cell death [35]. Therefore, we investigated if the cytokine-mediated induction of miRNAs was also dependent on NF- $\kappa \mathrm{B}$ activation in our study. Islets were pretreated for 2 hours with the NF- $\kappa$ B inhibitor Bay 117082 that inactivates $\mathrm{I} \kappa \mathrm{B}-\alpha$ phosphorylation [36] and then cultured with the cytokine cocktail. The high throughput miRNA assay using the Exiqon platform with SAM showed that blocking of NF- $\kappa$ B pathway caused significant reduction (on average more than $50 \%$, range $24-72 \%$ ) in the activation of most miRNAs tested (Table 2).

3.2. Islet miRNA Expression after Transplantation. Islet cells are exposed to multiple insults after transplantation $[37,38]$. To investigate the effect of in vivo inflammatory milieu on the expression of islet miRNAs, we transplanted rat islets under the kidney capsule of syngeneic recipients, an experimental model well suited to study early inflammatory events. Since the implanted islets remain in a well defined mass under the kidney capsule, they can be easily retrieved with minimal contamination from surrounding tissue for molecular evaluation [39]. The grafts were retrieved. MiRNA expression on islet grafts explanted 3 days after transplant $(n=3)$ was analyzed using LNA (Exiqon) microarrays and subsequent SAM. Nontransplanted islets taken from the same isolation served as controls. Explanted grafts yielded a pattern of 31 miRNAs with altered expression: 26 of them were upregulated and 5 downregulated. PCR-based TaqMan Low Density Arrays confirmed the expression of 11 miRNAs. Comparing the miRNA patterns of expression in the in vitro and in vivo experiments, we retrieved a subset of 26 miRNAs commonly regulated under both experimental conditions, 24 were upregulated and 2 downregulated (Table 3 ). Eight miRNAs from the PCR-confirmed 11 miRNAs, are common to both in vitro and in vivo inflammation conditions; 7 upregulated (miR-21, miR-98, miR-27a, miR-143, let-7d, miR-126 and miR-22) and one (miR-129) downregulated (Table 3).

\subsection{Inflammation-Induced miRNAs and Identification of} Their Potential Targets. MiRNAs downregulate their target mRNA levels causing inhibition of translation [40]. Furthermore, a recent study showed that destabilization of target mRNAs is the major reason for reduced protein expression mediated by miRNAs [41]. To identify potential miRNA targets, we integrated our high throughput miRNA expression data with previously published transcriptome studies. We expected that upregulated miRNAs would correspond to downregulated RNA targets and vice versa. Specifically we looked for inverse association between the expression of islet miRNAs modified by inflammation via both in vivo and in vitro conditions and the algorithmpredicted target genes found in a genome-wide mRNA (GWR) expression studies by Ortis et al. [27]. These authors studied the modification of genes in primary rat $\beta$-cells exposed in vitro to combination of the same cytokines we used in our study, namely IL- $1 \beta+$ IFN- $\gamma$ or TNF- $\alpha+$ IFN- $\gamma$ [27].

Two of the most commonly used computational miRNA predictive target programs are miRANDA and PicTar [4244]. It has been shown that perfect "seed" pairing is important for miRNA target recognition and predictability. The "seed" is the sequence corresponding to nucleotides 2-7 of the miRNA's 5 ' region [45]. The predictions by PicTar have a higher degree of overlap because these algorithms are based on stringent "seed" pairing, unlike miRBase that employs moderate "seed" pairing [46]. It has been reported that prediction of targets did not improve by using overlapping algorithms [47]. For that reason, rather than selecting the common targets to both algorithms, we chose PicTar algorithm to match upregulated miRNAs (miR-21, miR-98, miR27a, miR-143, let-7d, miR-126, miR-22) with downregulated putative targets in Ortis et al. and vice versa (Table 4). The PicTar algorithm identified 202 downregulated mRNAs which according to Ortis' study are potential targets for either of the above-mentioned upregulated miRNAs, and 36 upregulated mRNAs the possible targets for downregulated miR-129 (Table 4). From the 202 downregulated genes, 108 are targeted by one miRNA, and the rest are targeted by multiple miRNAs (data not shown). Interestingly, 30 genes are associated with regulation of insulin signal transduction pathways, development, and function of pancreatic islets, insulin secretion, and insulin resistance (Table 4). 
TABLE 1: miRNAs expressed in islets treated in vitro with a cocktail of IL-1 $\beta$, IFN- $\gamma$, and TNF- $\alpha$ were identified by SAM of global miRNAs. The score $(d)$ represents value of the T-statistic; a higher score means a greater difference between the two groups. $q$-values correspond to the $P$ values adapted to the analysis of a large number of genes. FI and SD are fold increase and standard deviation of hybridization values (cytokine versus control), respectively.

\begin{tabular}{|c|c|c|c|c|c|c|c|c|c|}
\hline Upregulated miRNAs & $(d)$ & $q(\%)$ & FI & SD & miRNA & $(d)$ & $q(\%)$ & FI & SD \\
\hline miR-143 & 6.7 & 0 & 7.5 & 3.5 & $\operatorname{miR}-27 a$ & 4.5 & 0 & 6.2 & 4.2 \\
\hline miR-30e & 6.0 & 0 & 15.3 & 11.4 & let-7a & 4.4 & 0 & 8.4 & 7.1 \\
\hline miR-182 & 6.0 & 0 & 9.1 & 4.8 & $\operatorname{miR}-375$ & 4.4 & 0 & 7.8 & 6.4 \\
\hline miR-96 & 6.0 & 0 & 13.6 & 9.4 & miR-30a & 4.4 & 0 & 5.3 & 3.3 \\
\hline miR-141 & 5.9 & 0 & 13.2 & 10.6 & $\operatorname{miR}-19 b$ & 4.3 & 0 & 6.6 & 4.5 \\
\hline miR-24 & 5.7 & 0 & 9.2 & 6.2 & let-7f & 4.3 & 0 & 19.8 & 25.4 \\
\hline $\operatorname{miR}-29 b$ & 5.5 & 0 & 12.7 & 11.2 & miR-16 & 4.1 & 0 & 4.7 & 2.9 \\
\hline $\operatorname{miR}-212$ & 5.5 & 0 & 9.8 & 7.0 & $\operatorname{miR}-29 c$ & 4.1 & 0 & 10.6 & 10.2 \\
\hline miR-7a & 5.2 & 0 & 10.7 & 8.6 & miR-103 & 4.1 & 0 & 3.0 & 0.9 \\
\hline miR-19a & 5.2 & 0 & 3.9 & 1.3 & miR-148b-3p & 4.0 & 0 & 7.1 & 6.1 \\
\hline let-7i & 5.2 & 0 & 13.7 & 9.6 & miR-30d & 3.9 & 0 & 4.1 & 2.3 \\
\hline miR-153 & 5.1 & 0 & 25.0 & 27.8 & miR-301a & 3.9 & 0 & 22.3 & 26.5 \\
\hline miR-22 & 5.1 & 0 & 4.7 & 1.9 & let-7c & 3.9 & 0 & 5.1 & 3.5 \\
\hline miR-27b & 5.0 & 0 & 8.1 & 5.7 & $\operatorname{miR}-23 b$ & 3.8 & 0 & 4.3 & 2.5 \\
\hline miR-21 & 5.0 & 0 & 10.2 & 6.5 & miR-29a & 3.7 & 0 & 5.8 & 4.5 \\
\hline miR-30b-5p & 5.0 & 0 & 6.6 & 4.2 & miR-23a & 3.6 & 0 & 4.3 & 2.6 \\
\hline let-7d & 4.9 & 0 & 9.6 & 7.7 & miR-204 & 3.6 & 0 & 7.4 & 8.2 \\
\hline miR-30c & 4.8 & 0 & 6.5 & 4.0 & miR-541 & 2.9 & 0 & 13.1 & 16.0 \\
\hline miR-200a & 4.8 & 0 & 13.0 & 11.5 & miR-99b & 2.9 & 0 & 13.1 & 1.3 \\
\hline miR-207 & 4.8 & 0 & 4.6 & 2.2 & rno-let-7b & 2.8 & 0 & 3.6 & 2.3 \\
\hline miR-183 & 4.8 & 0 & 4.7 & 2.0 & miR-125b-5p & 2.7 & 0 & 3.0 & 1.7 \\
\hline miR-127 & 4.8 & 0 & 7.6 & 3.8 & miR-17/17-5p & 2.7 & 0 & 9.9 & 14.2 \\
\hline miR-107 & 4.7 & 0 & 6.0 & 3.7 & miR-194 & 2.5 & 0 & 2.9 & 1.8 \\
\hline miR-335 & 4.7 & 0 & 2.8 & 0.7 & miR-200c & 2.4 & 0 & 2.6 & 1.4 \\
\hline miR-101a & 4.7 & 0 & 3.9 & 2.7 & miR-125a-5p & 2.4 & 0 & 2.6 & 1.5 \\
\hline miR-26a & 4.7 & 0 & 6.5 & 4.5 & miR-200b & 2.3 & 0 & 2.7 & 1.5 \\
\hline miR-98 & 4.6 & 0 & 9.3 & 7.8 & miR-340-5p & 2.2 & 0 & 2.3 & 1.1 \\
\hline miR-7b & 4.6 & 0 & 14.0 & 13.4 & let-7e & 2.0 & 0 & 2.3 & 1.1 \\
\hline miR-126 & 4.5 & 0 & 4.5 & 2.2 & $\operatorname{miR}-337$ & 2.0 & 0 & 2.0 & 2.3 \\
\hline miR-106b & 4.5 & 0 & 4.0 & 1.5 & & & & & \\
\hline Downregulated miRNAs & $(d)$ & $q(\%)$ & FI & SD & & & & & \\
\hline miR-185 & -2.8 & 0 & 4.0 & 3.3 & & & & & \\
\hline $\operatorname{miR}-129$ & -3.0 & 0 & 2.8 & 1.5 & & & & & \\
\hline miR-503 & -3.2 & 0 & 4.1 & 3.2 & & & & & \\
\hline $\operatorname{miR}-370$ & -3.4 & 0 & 3.5 & 2.1 & & & & & \\
\hline miR-206 & -4.3 & 0 & 2.6 & 0.7 & & & & & \\
\hline
\end{tabular}

3.4. Regulation of Endogenous mRNA by miR-21. To further test whether some of these 30 genes (Table 4) could be associated functionally with specific miRNAs, we studied selected miRNA overexpression effect on putative endogenous mRNA targets in the mouse insulin-secreting cell line MIN6. Since miR-21 was identified as the most reproducibly induced miRNA in vitro and in vivo, with the highest score " $d$ " in SAM analysis (Table 3 ), we focused on this miRNA. Programmed cell death $4(\operatorname{Pdcd} 4)$ and Piccolo (Pclo) are miR-21 potential targets (Table 4 ). Pdcd4 is a tumor suppressor gene that inhibits neoplastic transformation, tumor progression, and translation. It has been identified as miR-21 target in several systems [84]. Pclo is a high molecular weight $(550 \mathrm{kDa})$, multidomain protein functioning as a scaffold for proteins involved in synaptic vesicle endo- and exocytosis near their site of action. Pclo is proposed to function as $\mathrm{Ca}^{2+}$ sensor protein in cAMP insulin secretion in islets [50]. In vitro treatment of MIN6 cells with cytokines induced the expression of miR-21 (Figure 1(a)). Overexpression of miR-21 achieved by the addition of a mimic miR-21, but not of an irrelevant mimic miRNA (control), decreased the expression of both Pdcd4 and Pclo mRNAs in MIN6 cells (Figure 1(b)). It has been described that Pclo consists of two major splicing versions: 
TABLe 2: miRNAs selected by SAM analysis of global miRNA expression in islets exposed in vitro to cytokines with or without inhibition of the NF- $\kappa \mathrm{B}$ pathway. Values are expressed as percentage of values obtained with NF- $\kappa$ B inhibitor Bay 11-7082 plus cytokines versus cytokines alone.

\begin{tabular}{|c|c|c|c|}
\hline miRNA & $\begin{array}{c}\text { CTK + Bay } \\
\text { versus CTK (\%) }\end{array}$ & miRNA & $\begin{array}{c}\text { CTK + Bay } \\
\text { versus CTK (\%) }\end{array}$ \\
\hline miR-206 & 72.8 & miR-143 & 33.70 \\
\hline miR-17/17-5p & 61.8 & miR-24 & 33.71 \\
\hline miR-541 & 59.1 & $\operatorname{miR}-370$ & 33.71 \\
\hline miR-101a & 57.6 & miR-96 & 33.28 \\
\hline miR-503 & 54.0 & miR-125a-5p & 32.87 \\
\hline miR-106b & 52.5 & miR-200a & 32.82 \\
\hline miR-194 & 51.0 & miR-16 & 32.79 \\
\hline miR-204 & 50.9 & miR-99b & 32.70 \\
\hline miR-148b-3p & 49.6 & miR-26a & 32.44 \\
\hline miR-19a & 48.3 & miR-200c & 32.43 \\
\hline miR-19b & 46.2 & miR-337 & 32.39 \\
\hline miR-129 & 45.9 & $\operatorname{miR}-30 \mathrm{c}$ & 32.12 \\
\hline miR-301a & 41.4 & miR-7a & 32.03 \\
\hline miR-30d & 40.6 & miR-23a & 31.92 \\
\hline miR-127 & 40.2 & $\operatorname{miR}-27 a$ & 31.91 \\
\hline miR-335 & 39.4 & miR-30b-5p & 31.81 \\
\hline rno-let-7f & 39.4 & miR-200b & 31.67 \\
\hline miR-183 & 38.5 & miR-125b-5p & 31.63 \\
\hline miR-212 & 38.4 & miR-375 & 30.78 \\
\hline rno-let-7e & 37.7 & rno-let-7b & 30.71 \\
\hline miR-22 & 36.9 & $\operatorname{miR}-27 b$ & 30.63 \\
\hline miR-29a & 36.3 & rno-let-7d & 30.60 \\
\hline miR-98 & 36.1 & rno-let-7c & 30.57 \\
\hline miR-23b & 35.8 & rno-let-7a & 30.31 \\
\hline miR-185 & 35.7 & miR-153 & 29.32 \\
\hline miR-182 & 35.3 & miR-30e & 29.21 \\
\hline miR-207 & 35.3 & miR-141 & 29.20 \\
\hline $\operatorname{miR}-340-5 p$ & 35.3 & miR-29b & 28.11 \\
\hline miR-107 & 34.8 & miR-30a & 27.84 \\
\hline miR-126 & 34.3 & rno-let-7i & 27.65 \\
\hline miR-7b & 33.9 & miR-21 & 25.75 \\
\hline miR-103 & 33.8 & $\operatorname{miR}-29 c$ & 24.66 \\
\hline
\end{tabular}

V1 and V2 [85]. Their biological role is not currently known. Only V2 has an miR-21 recognition site in its 3'UTR. The miR-21: Pclo interaction site has a mismatch in the "seed" region; however, it displays a more extensive base pairing at the $3^{\prime}$ end of the miRNA (Figure $1(\mathrm{c})$ ). Semiquantitative PCR analysis showed that Pclo V2 is predominant in MIN6 cells (Figure 1(d)). Therefore, we could confirm the specificity of miR-21 to induce downregulation of endogenous Pclo in $\beta$-cells. These results suggest that in pancreatic islets miR-21 targets both Pdcd4 and Pclo genes.

\section{Discussion}

Islets of Langerhans are highly vascularized endocrine cell clusters located in the pancreas. The islet isolation process utilizes fragmentation of the gland to free the islets from the surrounding tissue, which results in a loss of vascular support. Consequently, the islets undergo hypoxic stress that persists until full revascularization in the recipient's microenvironment is completed, which may last several weeks [86]. Multiple factors, such as the duration of organ ischemia and the islet isolation process, contribute to activation of stress-induced signal transduction pathways and generation of inflammation mediators by islet cells [28]. Thus, islet cells participate actively in the initiation of local inflammation, which is further triggered by the transplant procedure. These responses may further amplify adaptive immunity responses after transplantation resulting in impairment of $\beta$-cell function and viability. Modulation of inflammatory responses in the early peritransplant period is associated with improved islet engraftment and function in both experimental and clinical settings. The purpose of our study was to identify islet microRNAs modulated in vitro and in vivo by inflammatory events. In the clinical settings, the islets are implanted into the hepatic portal system where they are exposed to blood, ischemia and activation of endothelium all contributing to the inflammatory reaction elicited in the transplant microenvironment. Unfortunately, it would be quite cumbersome to retrieve the graft from the liver for molecular analysis without introducing important biases (i.e., enzymatic digestion and purification to collect the islets otherwise randomly distributed into the liver parenchyma). Conversely, despite lacking key features of the intrahepatic site, the kidney subcapsular space allows the easy retrieval of the grafted tissue for molecular analysis with minimal manipulation.

The molecular pathways involved in islet cell response to inflammation during the peritransplant period are yet to be fully understood. Transcriptome analysis of explanted islet grafts has revealed a key involvement of NF- $\kappa \mathrm{B}$ pathway as an initial adaptation response to the new microenvironment and the underlying tissue remodeling during the peritransplant period [87].

The emerging role of miRNAs as master regulators of gene expression has opened new avenues toward the thorough understanding of cellular responses under various physiological and pathological conditions. Indeed, herein we report that miRNAs expression is regulated by the inflammatory milieu generated in transplanted islets. We have identified a pool of 26 miRNAs commonly affected by inflammation both in vivo and in vitro, suggesting their association with the intrinsic basic molecular mechanism determining the fate of islet grafts in the early posttransplant period.

Our study includes an integrated evaluation of miRNAs and mRNAs gene expression in insulin secreting cells along with functional studies identifying new targets for miRNAs activated by proinflammatory cytokines. Induction of miRNA transcription was partially dependent on activation of $\mathrm{NF}-\kappa \mathrm{B}$, a transcription factor with a critical role in 
TABLE 3: SAM of miRNAs expressed in transplanted syngeneic islets collected 3 days after implantation. MiRNA expression in transplanted islets was compared to control isolated islets. 26 common miRNAs that displayed altered expression in vivo and in vitro (cytokine treated islets) are shown in bold font. MiRNA confirmed by PCR are marked with an X in the last column. FI and SD are fold increase and standard deviation of hybridization values (transplanted islets versus control islets), respectively.

\begin{tabular}{|c|c|c|c|c|c|}
\hline Upregulated miRNAs & $(d)$ & $q-(\%)$ & FI & $\mathrm{SD}$ & PCR \\
\hline$m i R-21$ & 7.75 & 0.00 & 26.58 & 13.21 & $\mathrm{X}$ \\
\hline $\operatorname{miR}-98$ & 4.40 & 0.00 & 7.94 & 3.60 & $\mathrm{X}$ \\
\hline$m i R-212$ & 4.33 & 0.00 & 51.61 & 43.25 & \\
\hline$m i R-27 a$ & 4.15 & 0.00 & 19.56 & 14.07 & $\mathrm{X}$ \\
\hline rno-let-7i & 4.13 & 0.00 & 16.16 & 15.27 & \\
\hline $\operatorname{miR}-207$ & 4.01 & 0.00 & 20.62 & 15.18 & \\
\hline $\operatorname{miR}-143$ & 3.94 & 0.00 & 9.12 & 6.07 & $\mathrm{X}$ \\
\hline rno-let-7a & 3.89 & 0.00 & 13.03 & 9.55 & \\
\hline rno-let-7d & 3.89 & 0.00 & 7.20 & 3.30 & $\mathrm{X}$ \\
\hline$m i R-126$ & 3.83 & 0.00 & 41.18 & 60.44 & $\mathrm{X}$ \\
\hline miR-195 & 3.68 & 0.00 & 8.12 & 5.00 & $\mathrm{X}$ \\
\hline $\operatorname{miR}-22$ & 3.66 & 0.00 & 10.14 & 8.45 & $\mathrm{X}$ \\
\hline$m i R-27 b$ & 3.54 & 0.00 & 10.57 & 6.85 & \\
\hline$m i R-107$ & 3.49 & 0.00 & 8.16 & 5.90 & \\
\hline$m i R-99 b$ & 3.38 & 0.00 & 5.01 & 2.15 & \\
\hline $\operatorname{miR}-214$ & 3.34 & 0.00 & 10.52 & 7.15 & $\mathrm{X}$ \\
\hline$m i R-125 b-5 p$ & 3.33 & 0.00 & 8.13 & 4.95 & \\
\hline rno-let-7e & 3.20 & 0.00 & 3.76 & 1.37 & \\
\hline$m i R-23 a$ & 3.17 & 0.00 & 9.24 & 8.21 & \\
\hline rno-let-7b & 2.95 & 0.00 & 5.27 & 3.79 & \\
\hline$m i R-24$ & 2.93 & 0.00 & 7.61 & 6.34 & \\
\hline$m i R-30 e$ & 2.91 & 0.00 & 7.77 & 4.92 & \\
\hline$m i R-23 b$ & 2.87 & 0.00 & 7.37 & 6.20 & \\
\hline$m i R-26 a$ & 2.80 & 0.00 & 5.93 & 3.69 & \\
\hline $\operatorname{miR}-29 c$ & 2.77 & 0.00 & 6.97 & 4.10 & \\
\hline $\operatorname{miR}-375$ & 2.74 & 0.00 & 6.04 & 3.89 & \\
\hline Downregulated miRNAs & $(d)$ & $q-(\%)$ & FI & $\mathrm{SD}$ & PCR \\
\hline miR-542-5p & -6.03 & 0.00 & 19.82 & 11.24 & \\
\hline $\operatorname{miR}-129$ & -5.09 & 0.00 & 25.58 & 25.01 & $\mathrm{X}$ \\
\hline miR-326 & -3.03 & 0.00 & 5.89 & 4.12 & $\mathrm{X}$ \\
\hline$m i R-370$ & -2.85 & 0.00 & 4.78 & 1.87 & \\
\hline miR-484 & -2.55 & 0.00 & 11.70 & 2.74 & \\
\hline
\end{tabular}

$\beta$-cell apoptosis mediated by proinflammatory cytokines (Table 2) $[35,88]$. The convergence of miRNAs and NF $\kappa \mathrm{B}$ signaling pathway has been recently established [89]. Using quantitative PCR-based high throughput analysis, we have confirmed upregulation of 7 (miR-21, miR-98, miR-27a, miR-143, let-7d, miR-126, and miR-22) and downregulation of 1 (miR-129) miRNAs out of the 26 activated miRNAs identified in our settings. The relatively low number of miRNAs confirmed by RT-PCR in our study might be due to the low reproducibility of miRNA profiling interplatforms [90]. This may also explain why miRNAs previously reported in islets upon in vitro cytokine exposure, such as miR146 and miR-34a, were not confirmed in our study [25]. Some of the 8 miRNAs have been reported previously in studies related to islet physiology or diabetes. MiR-21 has a potential role in diabetic nephropathy [91]. Low plasma levels of miR-21 and miR-126 have been detected in patients with type 2 diabetes [92]. In agreement with our results, cytokines increased miR-21 expression in $\beta$-cells, while miR-21 downregulation conferred cytoprotection to islets exposed to IL- $1 \beta$ in vitro [25]. The expression patterns of miR-27a varied with hyperglycemia in the Gyoto-Kakizaki rat [5], and miRNA-143 overexpression inhibited insulinstimulated AKT activation and resulted in impaired glucose metabolism [93].

Our results suggest that overexpression of miR-21 in MIN6 cells could regulate the expression of Pdcd4 and Pclo steady-state mRNA levels. The tumor suppressor proinflammatory protein $\mathrm{Pdcd} 4$ promotes activation of the transcription factor NF- $\kappa$ B [94]. Downregulation of Pdcd4 


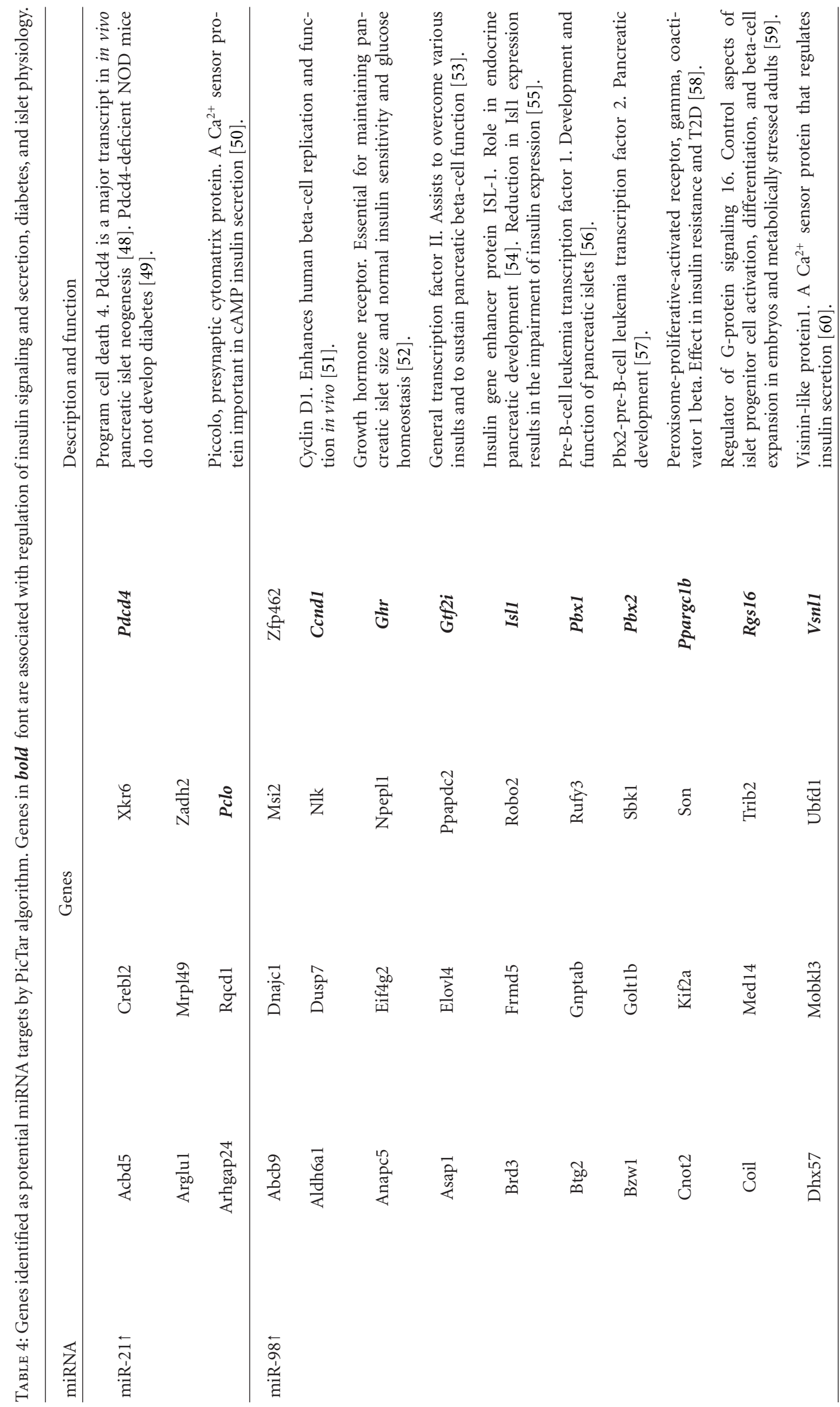




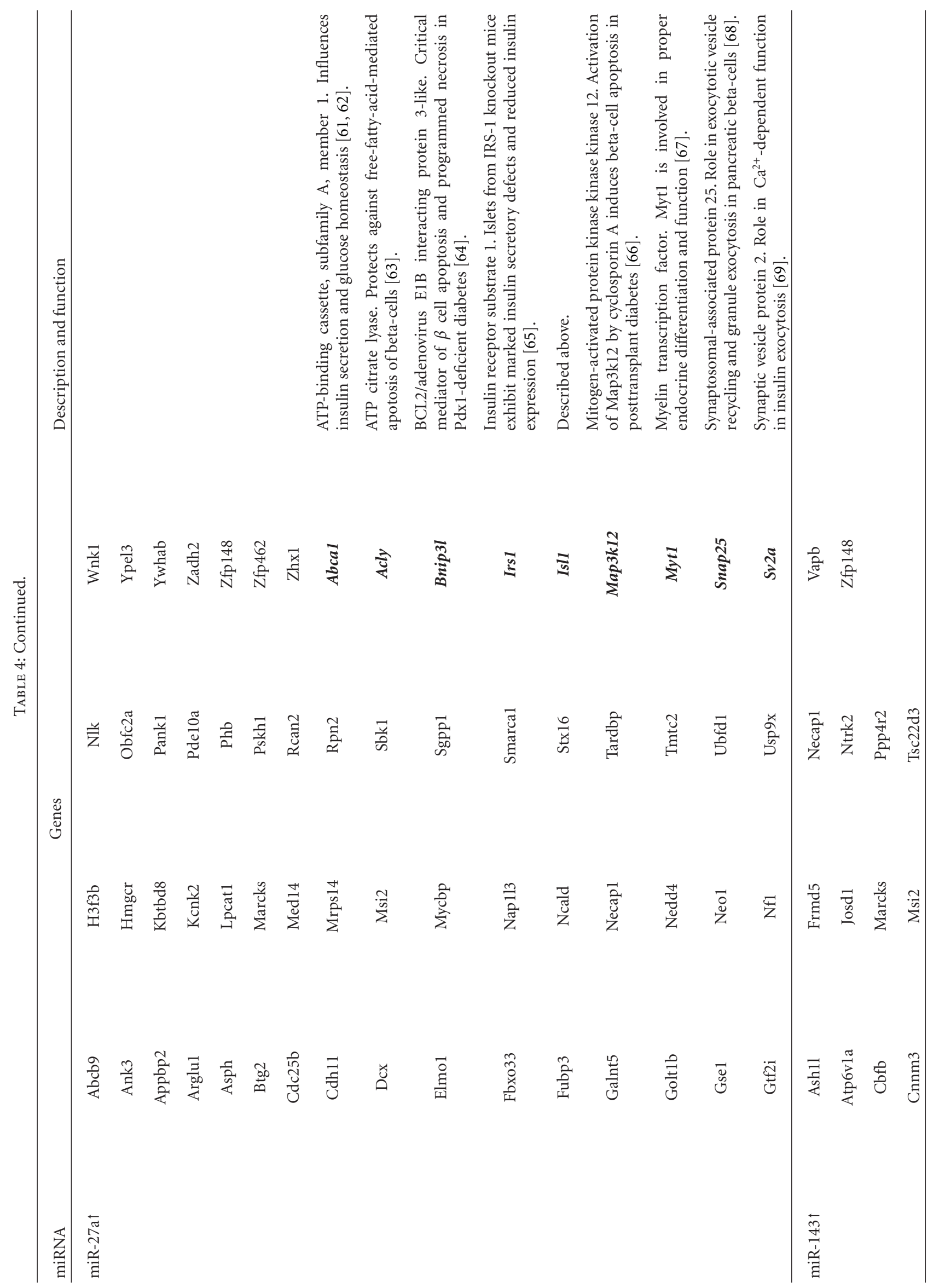




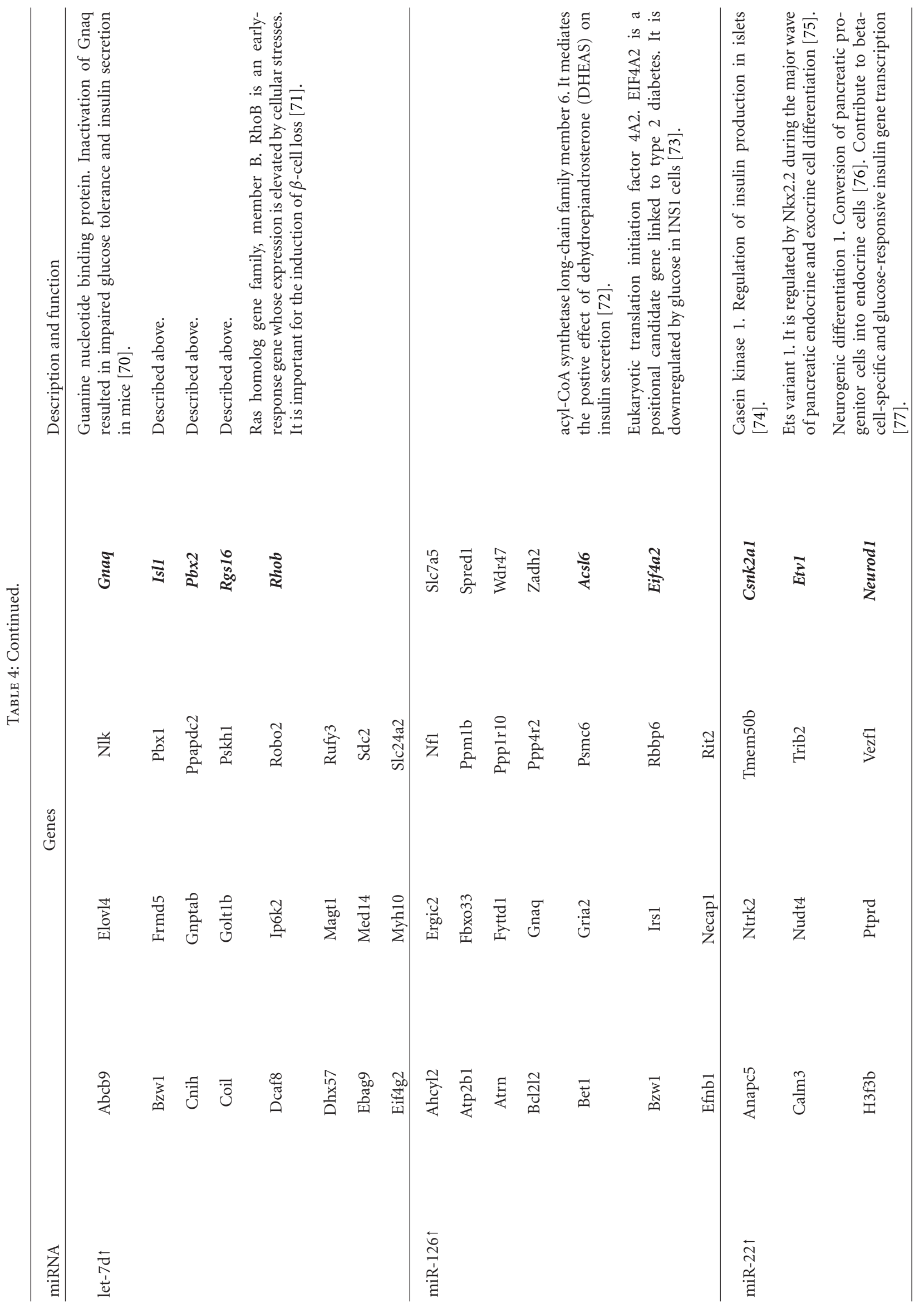




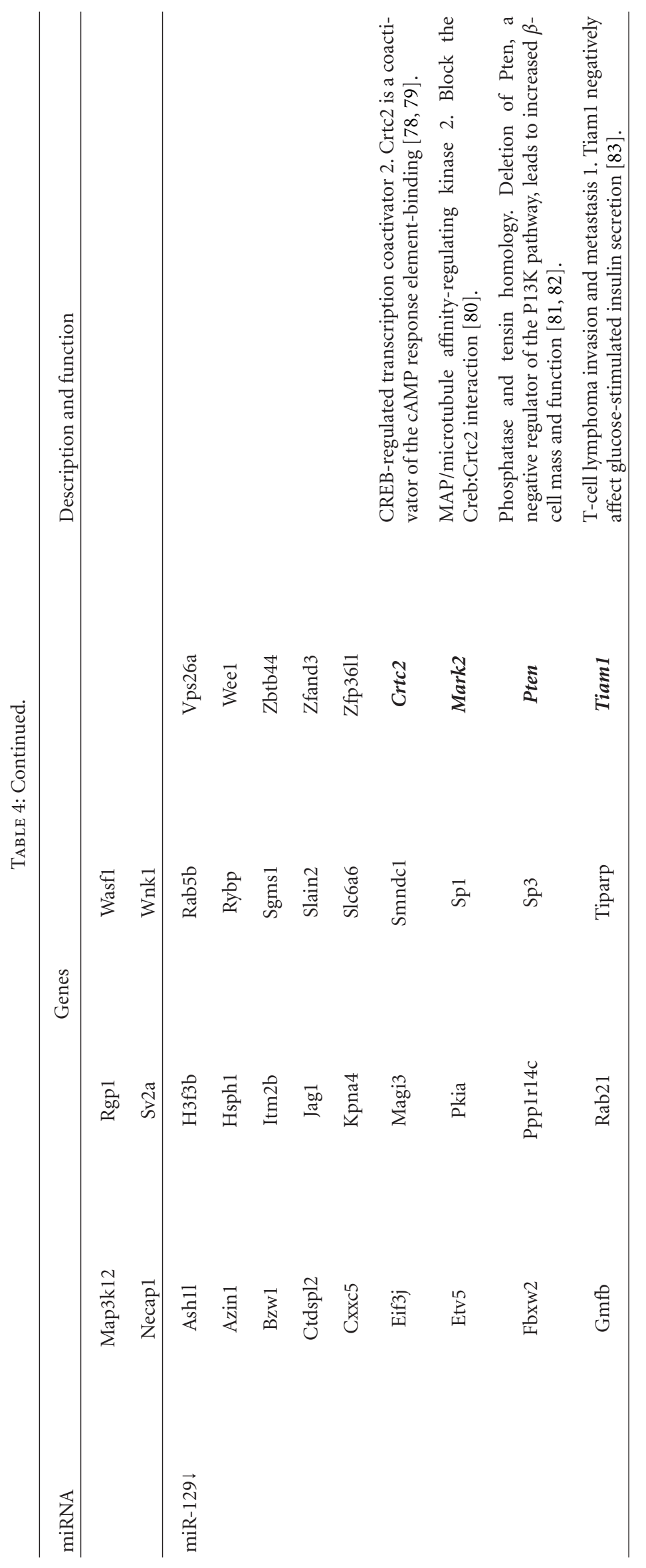




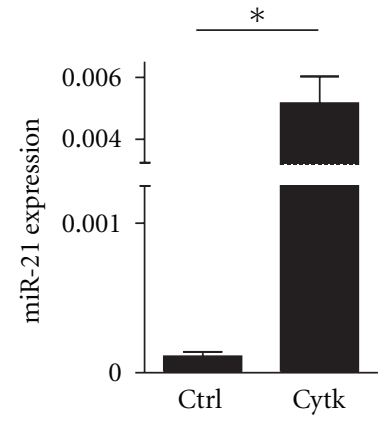

(a)
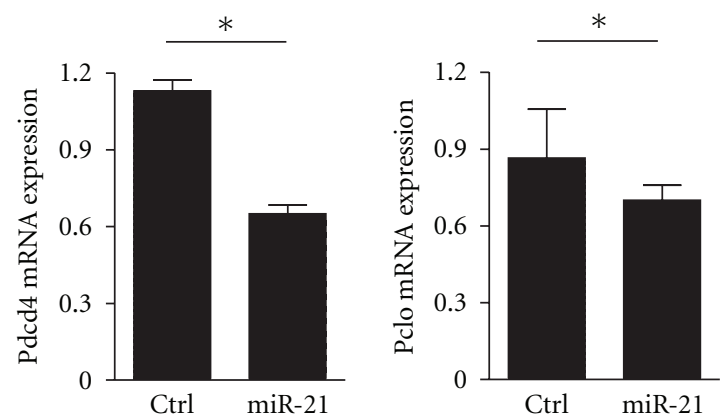

(b)

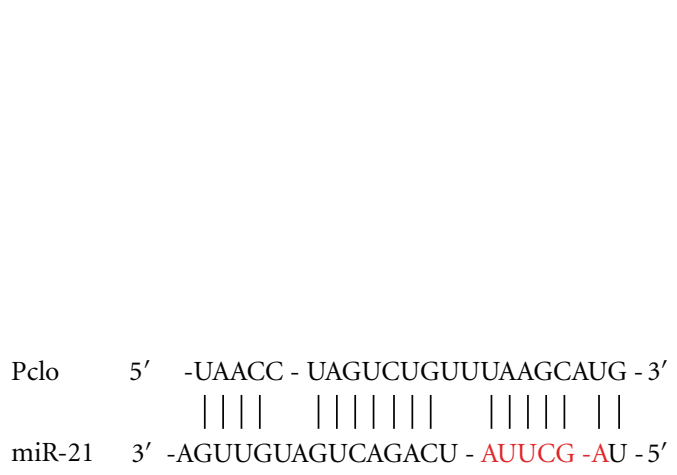

(c)

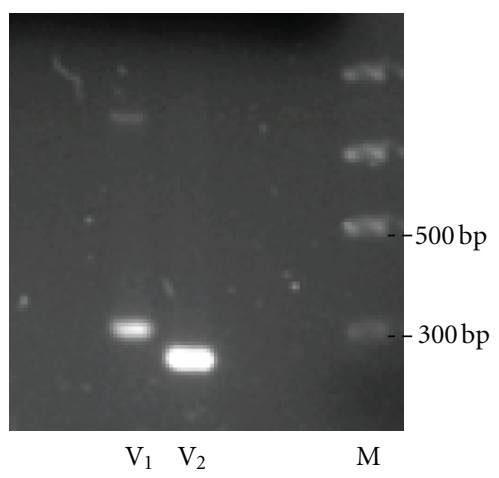

(d)

FIgure 1: Overexpression of miR-21 regulates endogenous Pdcd4 and Pclo mRNAs. (a) MIN6 cells were treated 24 hours with cytokine cocktail IL-1 $\beta(50 \mathrm{U} / \mathrm{mL})$, TNF- $\alpha(2000 \mathrm{U} / \mathrm{mL})$, and IFN $\gamma(100 \mathrm{U} / \mathrm{mL})$. The expression of miR-21 was assessed by qRT-PCR. (b) Overexpression of miR-21 mimic $(300 \mathrm{nM})$ for $48 \mathrm{hs}$ inhibits the expression of endogenous Pdcd 4 and Pclo mRNA. Experiments shown in (a) and (b) are expressed as mean $\pm \mathrm{SD}(n=5),{ }^{*} P<0.05$ (t-test, 2 tails). (c) miR-21 recognition site in the $3^{\prime} \mathrm{UTR}$ of Pclo splicing version 2. MiR-21 "seed" is shown in red font. (d) Semiquantitative RT-PCR shows expression of both Pclo versions (V1, V2) in MIN6 insulinoma cells.

by miR-21 has been associated with attenuation of cytotoxic effects of oxidative stress and ischemia-reperfusion in cardiomyocytes $[95,96]$, decreasing the proinflammatory effects of TLR4 signaling [94], and also preventing type 1 diabetes in rodents [49]. Furthermore, miR-21 targets the Pclo gene which acts as a $\mathrm{Ca}^{2+}$ sensor via formation of a cAMPGEFII(Epac2)-Rim2 complex in PKA-independent cAMP insulin secretion. Pclo inhibition impairs cAMP insulin secretion [50]. Therefore, miR-21 has the ability to regulate genes such as Pclo and Pdcd4 that might affect $\beta$-cells in conflicting manner. On one hand, during inflammation miR-21 contributes to the impairment of islet cells function by interfering with insulin exocytosis via downregulation of Pclo. On the other hand, miR-21 could reduce cytokinemediated apoptosis in $\beta$-cells via downregulation of Pdcd4. Divergent effects have been also reported in islets treated with cytokines for mRNAs, such as STAT1 and IRF-1 [97].

Collectively, our study and the results of previous reports regarding the effect of cytokines on gene expression in islet $\beta$-cells $[25-27,98]$ indicate that proinflammatory cytokines trigger a complex response resulting in modulation of the expression of islet mRNAs and miRNAs, which in some cases might affect the system in a seemingly contradictory fashion.
In the context of transplantation, it is likely that the final outcome of the cytokine effect on islet cells depends on the combination of factors, such as intensity and duration of exposure, and initial quality of the islet graft (i.e., viability).

In conclusion, we found a set of miRNAs that are regulated by inflammatory conditions in transplanted islets. In addition, the theoretical bioinformatics analysis identified potential genes that are directly regulated by these miRNAs. This information could be helpful for future studies of novel genes involved in inflammation-mediated $\beta$-cells dysfunction as well as for the development of new therapeutic applications.

\section{Acknowledgments}

This paper was supported by the Diabetes Research Institute Foundation (to A. Pileggi and R. L. Pastori), the Karasik Foundation (R. L. Pastori), the Peacock Foundation (R. L. Pastori), and by a postdoctoral minority fellowship from the American Diabetes Association (R. L. Pastori). Invaluable assistance was obtained by Diabetes Research Institute's Cores (Preclinical Cell Processing \& Translational Models, Imaging, Flow Cytometry, Histology, and Administrative). 


\section{References}

[1] S. P. Hussain and C. C. Harris, "Inflammation and cancersan ancient link with novel potentials," International Journal of Cancer, vol. 121, no. 11, pp. 2373-2380, 2007.

[2] D. L. Eizirik, M. L. Colli, and F. Ortis, "The role of inflammation in insulitis and $\beta$-cell loss in type 1 diabetes," Nature Reviews Endocrinology, vol. 5, no. 4, pp. 219-226, 2009.

[3] M. S. Baker, X. Chen, A. Rotramel, J. Nelson, and D. B. Kaufman, "Proinflammatory cytokines induce NF- $\kappa$ BDependent/NO-independent chemokine gene expression in MIN6 $\beta$ cells," Journal of Surgical Research, vol. 110, no. 1, pp. 295-303, 2003.

[4] H. Baquerizo and A. Rabinovitch, "Interferon-gamma sensitizes rat pancreatic islet cells to lysis by cytokines and cytotoxic cells," Journal of Autoimmunity, vol. 3, no. 2, pp. 123-130, 1990.

[5] H. E. Hohmeier, V. V. Tran, G. Chen, R. Gasa, and C. B. Newgard, "Inflammatory mechanisms in diabetes: lessons from the $\beta$-cell," International Journal of Obesity, vol. 27, supplement 3, pp. S12-S16, 2003.

[6] S. Sandler, D. L. Eizirik, J. Sternesjo, and N. Welsh, "Role of cytokines in regulation of pancreatic B-cell function," Biochemical Society Transactions, vol. 22, no. 1, pp. 26-30, 1994.

[7] M. Y. Donath, D. M. Schumann, M. Faulenbach, H. Ellingsgaard, A. Perren, and J. A. Ehses, "Islet inflammation in type 2 diabetes: from metabolic stress to therapy," Diabetes care, vol. 31, supplement 2, pp. S161-S164, 2008.

[8] C. J. Nolan, M. S. R. Madiraju, V. Delghingaro-Augusto, M. L. Peyot, and M. Prentki, "Fatty acid signaling in the $\beta$-cell and insulin secretion," Diabetes, vol. 55, supplement 2, pp. S16S23, 2006

[9] V. Poitout and R. P. Robertson, "Glucolipotoxicity: fuel excess and $\beta$-cell dysfunction," Endocrine Reviews, vol. 29, no. 3, pp. 351-366, 2008.

[10] S. Matsumoto, M. Takita, D. Chaussabel et al., "Improving efficacy of clinical islet transplantation with iodixanol-based islet purification, thymoglobulin induction, and blockage of IL- $1 \beta$ and TNF- $\alpha$," Cell Transplantation, vol. 20, no. 10, pp. 1641-1647, 2011.

[11] C. Toso, V. Serre-Beinier, J. Emamaullee et al., "The role of macrophage migration inhibitory factor in mouse islet transplantation," Transplantation, vol. 86, no. 10, pp. 1361$1369,2008$.

[12] L. Moberg, "The role of the innate immunity in islet transplantation," Upsala Journal of Medical Sciences, vol. 110, no. 1, pp. 17-55, 2005.

[13] A. Pileggi, R. Damaris Molano, T. Berney et al., "Heme oxygenase-1 induction in islet cells results in protection from apoptosis and improved in vivo function after transplantation," Diabetes, vol. 50, no. 9, pp. 1983-1991, 2001.

[14] A. Pileggi, R. D. Molano, T. Berney et al., "Prolonged allogeneic islet graft survival by protoporphyrins," Cell Transplantation, vol. 14, no. 2-3, pp. 85-96, 2005.

[15] V. Ambros, "The functions of animal microRNAs," Nature, vol. 431, no. 7006, pp. 350-355, 2004.

[16] D. P. Bartel, "MicroRNAs: genomics, biogenesis, mechanism, and function," Cell, vol. 116, no. 2, pp. 281-297, 2004.

[17] T. Nakasa, S. Miyaki, A. Okubo et al., "Expression of MicroRNA-146 in rheumatoid arthritis synovial tissue," Arthritis and Rheumatism, vol. 58, no. 5, pp. 1284-1292, 2008.
[18] R. M. O'Connell, K. D. Taganov, M. P. Boldin, G. Cheng, and D. Baltimore, "MicroRNA-155 is induced during the macrophage inflammatory response," Proceedings of the National Academy of Sciences of the United States of America, vol. 104, no. 5, pp. 1604-1609, 2007.

[19] E. Sonkoly, M. Ståhle, and A. Pivarcsi, "MicroRNAs and immunity: novel players in the regulation of normal immune function and inflammation," Seminars in Cancer Biology, vol. 18, no. 2, pp. 131-140, 2008.

[20] C. Urbich, A. Kuehbacher, and S. Dimmeler, "Role of microRNAs in vascular diseases, inflammation, and angiogenesis," Cardiovascular Research, vol. 79, no. 4, pp. 581-588, 2008.

[21] C. Guay, E. Roggli, V. Nesca, C. Jacovetti, and R. Regazzi, "Diabetes mellitus, a microRNA-related disease?" Translational Research, vol. 157, no. 4, pp. 253-264, 2011.

[22] B. M. Herrera, H. E. Lockstone, J. M. Taylor et al., "Global microRNA expression profiles in insulin target tissues in a spontaneous rat model of type 2 diabetes," Diabetologia, vol. 53, no. 6, pp. 1099-1109, 2010.

[23] X. Tang, G. Tang, and S. Özcan, "Role of microRNAs in diabetes," Biochimica et Biophysica Acta, vol. 1779, no. 11, pp. 697-701, 2008.

[24] J. L. S. Esguerra, C. Bolmeson, C. M. Cilio, and L. Eliasson, "Differential glucose-regulation of microRNAs in pancreatic islets of non-obese type 2 diabetes model Goto-Kakizaki rat," PLoS One, vol. 6, no. 4, Article ID e18613, 2011.

[25] E. Roggli, A. Britan, S. Gattesco et al., "Involvement of microRNAs in the cytotoxic effects exerted by proinflammatory cytokines on pancreatic $\beta$-cells," Diabetes, vol. 59, no. 4, pp. 978-986, 2010.

[26] A. K. Cardozo, M. Kruhøffer, R. Leeman, T. Ørntoft, and D. L. Eizirik, "Identification of novel cytokine-induced genes in pancreatic $\beta$-cells by high-density oligonucleotide arrays," Diabetes, vol. 50, no. 5, pp. 909-920, 2001.

[27] F. Ortis, N. Naamane, D. Flamez et al., "Cytokines interleukin$1 \beta$ and tumor necrosis factor- $\alpha$ regulate different transcriptional and alternative splicing networks in primary $\beta$-cells," Diabetes, vol. 59, no. 2, pp. 358-374, 2010.

[28] A. Pileggi, M. M. Ribeiro, A. R. Hogan et al., "Impact of pancreatic cold preservation on rat islet recovery and function," Transplantation, vol. 87, no. 10, pp. 1442-1450, 2009.

[29] P. Cattan, T. Berney, S. Schena et al., "Early assessment of apoptosis in isolated islets of langerhans," Transplantation, vol. 71, no. 7, pp. 857-862, 2001.

[30] V. G. Tusher, R. Tibshirani, and G. Chu, "Significance analysis of microarrays applied to the ionizing radiation response," Proceedings of the National Academy of Sciences of the United States of America, vol. 98, no. 9, pp. 5116-5121, 2001.

[31] K. Bendtzen, T. Mandrup-Poulsen, and J. Nerup, "Cytotoxicity of human pI 7 Interleukin-1 for pancreatic islets of Langerhans," Science, vol. 232, no. 4757, pp. 1545-1547, 1986.

[32] D. L. Eizirik, S. Sandler, N. Welsh et al., "Cytokines suppress human islet function irrespective of their effects on nitric oxide generation," The Journal of Clinical Investigation, vol. 93, no. 5, pp. 1968-1974, 1994.

[33] M. Castoldi, S. Schmidt, V. Benes et al., "A sensitive array for microRNA expression profiling (miChip) based on locked nucleic acids (LNA)," RNA, vol. 12, no. 5, pp. 913-920, 2006.

[34] H. Willenbrock, J. Salomon, R. Søkilde et al., "Quantitative miRNA expression analysis: comparing microarrays with next-generation sequencing," $R N A$, vol. 15, no. 11, pp. 20282034, 2009. 
[35] A. K. Cardozo, H. Heimberg, Y. Heremans et al., "A comprehensive analysis of cytokine-induced and nuclear factor-kappa B-dependent genes in primary rat pancreatic beta-cells," The Journal of Biological Chemistry, vol. 276, no. 52, pp. 4887948886, 2001.

[36] J. W. Pierce, R. Schoenleber, G. Jesmok et al., "Novel inhibitors of cytokine-induced $\mathrm{I} \kappa \mathrm{B} \alpha$ phosphorylation and endothelial cell adhesion molecule expression show anti-inflammatory effects in vivo," The Journal of Biological Chemistry, vol. 272, no. 34, pp. 21096-21103, 1997.

[37] N. R. Barshes, S. Wyllie, and J. A. Goss, "Inflammationmediated dysfunction and apoptosis in pancreatic islet transplantation: implications for intrahepatic grafts," Journal of Leukocyte Biology, vol. 77, no. 5, pp. 587-597, 2005.

[38] U. Johansson, A. Olsson, S. Gabrielsson, B. Nilsson, and O. Korsgren, "Inflammatory mediators expressed in human islets of Langerhans: implications for islet transplantation," Biochemical and Biophysical Research Communications, vol. 308, no. 3, pp. 474-479, 2003.

[39] D. R. Laybutt, Y. C. Hawkins, J. Lock et al., "Influence of diabetes on the loss of beta cell differentiation after islet transplantation in rats," Diabetologia, vol. 50, no. 10, pp. $2117-$ 2125, 2007.

[40] L. P. Lim, N. C. Lau, P. Garrett-Engele et al., "Microarray analysis shows that some microRNAs downregulate large numbers of-target mRNAs," Nature, vol. 433, no. 7027, pp. 769-773, 2005.

[41] H. Guo, N. T. Ingolia, J. S. Weissman, and D. P. Bartel, "Mammalian microRNAs predominantly act to decrease target mRNA levels," Nature, vol. 466, no. 7308, pp. 835-840, 2010.

[42] S. Griffiths-Jones, R. J. Grocock, S. van Dongen, A. Bateman, and A. J. Enright, "miRBase: microRNA sequences, targets and gene nomenclature," Nucleic Acids Research, vol. 34, pp. D140D144, 2006.

[43] A. Grimson, K. K. H. Farh, W. K. Johnston, P. Garrett-Engele, L. P. Lim, and D. P. Bartel, "MicroRNA targeting specificity in mammals: determinants beyond seed pairing," Molecular Cell, vol. 27, no. 1, pp. 91-105, 2007.

[44] N. Rajewsky, "microRNA target predictions in animals," Nature Genetics, vol. 38, supplement, pp. S8-S13, 2006.

[45] B. P. Lewis, I. H. Shih, M. W. Jones-Rhoades, D. P. Bartel, and C. B. Burge, "Prediction of mammalian MicroRNA targets," Cell, vol. 115, no. 7, pp. 787-798, 2003.

[46] D. P. Bartel, "MicroRNAs: target recognition and regulatory functions," Cell, vol. 136, no. 2, pp. 215-233, 2009.

[47] W. Ritchie, S. Flamant, and J. E. J. Rasko, "Predicting microRNA targets and functions: traps for the unwary," Nature Methods, vol. 6, no. 6, pp. 397-398, 2009.

[48] W. F. Ferris, C. E. Marriott, T. Ali, C. Landy, S. C. Campbell, and W. M. MacFarlane, "Tumor suppressor Pdcd4 is a major transcript that is upregulated during in vivo pancreatic islet neogenesis and is expressed in both beta-cell and ductal cell lines," Pancreas, vol. 40, no. 1, pp. 61-66, 2011.

[49] Q. Ruan, T. Wang, V. Kameswaran et al., "The microRNA-21PDCD4 axis prevents type 1 diabetes by blocking pancreatic $\beta$ cell death," Proceedings of the National Academy of Sciences of the United States of America, vol. 108, no. 29, pp. 12030-12035, 2011.

[50] K. Fujimoto, T. Shibasaki, N. Yokoi et al., "Piccolo, a $\mathrm{Ca}^{2+}$ sensor in pancreatic $\beta$-cells: involvement of cAMP-GEFIIRim2 Piccolo complex in cAMP-dependent exocytosis," The
Journal of Biological Chemistry, vol. 277, no. 52, pp. 5049750502, 2002.

[51] N. Fiaschi-Taesch, T. A. Bigatel, B. Sicari et al., "Survey of the human pancreatic $\beta$-cell G1/S proteome reveals a potential therapeutic role for dk-6 and Cyclin D1 in Enhancing Human $\beta$-cell replication and function in vivo," Diabetes, vol. 58, no. 4, pp. 882-893, 2009.

[52] J.-L. Liu, K. T. Coschigano, K. Robertson et al., "Disruption of growth hormone receptor gene causes diminished pancreatic islet size and increased insulin sensitivity in mice," American Journal of Physiology, vol. 287, no. 3, pp. E405-E413, 2004.

[53] A. Inberg and M. Linial, "Protection of pancreatic $\beta$-cells from various stress conditions is mediated by DJ-1," The Journal of Biological Chemistry, vol. 285, no. 33, pp. 25686-25698, 2010.

[54] U. Ahlgren, S. L. Pfaff, T. M. Jessell, T. Edlund, and H. Edlund, "Independent requirement for ISL1 in formation of pancreatic mesenchyme and islet cells," Nature, vol. 385, no. 6613, pp. 257-260, 1997.

[55] H. Zhang, W. P. Wang, T. Guo et al., “The LIM-homeodomain protein ISL1 activates insulin gene promoter directly through synergy with BETA2," Journal of Molecular Biology, vol. 392, no. 3, pp. 566-577, 2009.

[56] S. K. Kim, L. Selleri, J. S. Lee et al., "Pbx1 inactivation disrupts pancreas development and in Ipf1-deficient mice promotes diabetes mellitus," Nature Genetics, vol. 30, no. 4, pp. 430-435, 2002.

[57] X. Zhang, S. Rowan, Y. Yue et al., "Pax6 is regulated by Meis and Pbx homeoproteins during pancreatic development," Developmental Biology, vol. 300, no. 2, pp. 748-757, 2006.

[58] M. E. Patti, A. J. Butte, S. Crunkhorn et al., "Coordinated reduction of genes of oxidative metabolism in humans with insulin resistance and diabetes: potential role of PGC1 and NRF1," Proceedings of the National Academy of Sciences of the United States of America, vol. 100, no. 14, pp. 8466-8471, 2003.

[59] A. Villasenor, Z. V. Wang, L. B. Rivera et al., "Rgs16 and Rgs8 in embryonic endocrine pancreas and mouse models of diabetes," DMM Disease Models and Mechanisms, vol. 3, no. 9-10, pp. 567-580, 2010.

[60] F. F. Dai, Y. Zhang, Y. Kang et al., "The neuronal $\mathrm{Ca}^{2+}$ sensor protein visinin-like protein-1 is expressed in pancreatic islets and regulates insulin secretion," The Journal of Biological Chemistry, vol. 281, no. 31, pp. 21942-21953, 2006.

[61] M. Vergeer, L. R. Brunham, J. Koetsveld et al., "Carriers of loss-of-function mutations in ABCA1 display pancreatic $\beta$-cell dysfunction," Diabetes Care, vol. 33, no. 4, pp. 869-874, 2010.

[62] J. Li, K. Murao, H. Imachi et al., "Exendin-4 regulates pancreatic ABCA1 transcription via CaMKK/CaMKIV pathway," Journal of Cellular and Molecular Medicine, vol. 14, no. 5, pp. 1083-1087, 2010.

[63] K. Y. Chu, Y. Lin, A. Hendel, J. E. Kulpa, R. W. Brownsey, and J. D. Johnson, "ATP-citrate lyase reduction mediates palmitateinduced apoptosis in pancreatic beta cells," The Journal of Biological Chemistry, vol. 285, no. 42, pp. 32606-32615, 2010.

[64] K. Fujimoto, E. L. Ford, H. Tran et al., "Loss of Nix in Pdx1deficient mice prevents apoptotic and necrotic $\beta$ cell death and diabetes," The Journal of Clinical Investigation, vol. 120, no. 11, pp. 4031-4039, 2010.

[65] R. N. Kulkarni, J. N. Winnay, M. Daniels et al., “Altered function of insulin receptor substrate 1-deficient mouse islets and cultured $\beta$-cell lines," The Journal of Clinical Investigation, vol. 104, no. 12, pp. R69-R75, 1999.

[66] S. Plaumann, R. Blume, S. Börchers, H. J. Steinfelder, W. Knepel, and E. Oetjen, "Activation of the dual-leucine-zipperbearing kinase and induction of $\beta$-cell apoptosis by the 
immunosuppressive drug cyclosporin A," Molecular Pharmacology, vol. 73, no. 3, pp. 652-659, 2008.

[67] S. Wang, J. Zhang, A. Zhao, S. Hipkens, M. A. Magnuson, and G. Gu, "Loss of Myt1 function partially compromises endocrine islet cell differentiation and pancreatic physiological function in the mouse," Mechanisms of Development, vol. 124, no. 11-12, pp. 898-910, 2007.

[68] A. F. Jeans, P. L. Oliver, R. Johnson et al., "A dominant mutation in Snap25 causes impaired vesicle trafficking, sensorimotor gating, and ataxia in the blind-drunk mouse," Proceedings of the National Academy of Sciences of the United States of America, vol. 104, no. 7, pp. 2431-2436, 2007.

[69] M. Iezzi, S. Theander, R. Janz, C. Loze, and C. B. Wollheim, "SV2A and SV2C are not vesicular $\mathrm{Ca}^{2+}$ transporters but control glucose-evoked granule recruitment," Journal of Cell Science, vol. 118, part 23, pp. 5647-5660, 2005.

[70] A. Sassmann, B. Gier, H. J. Gröne, G. Drews, S. Offermanns, and N. Wettschureck, "The Gq/G11-mediated signaling pathway is critical for autocrine potentiation of insulin secretion in mice," The Journal of Clinical Investigation, vol. 120, no. 6, pp. 2184-2193, 2010.

[71] A. Bravo-Nuevo, H. Sugimoto, S. Iyer et al., "RhoB loss prevents streptozotocin-induced diabetes and ameliorates diabetic complications in mice," American Journal of Pathology, vol. 178, no. 1, pp. 245-252, 2011.

[72] J. S. Dillon, G. C. Yaney, Y. Zhou et al., "Dehydroepiandrosterone sulfate and $\beta$-cell function: enhanced glucose-induced insulin secretion and altered gene expression in rodent pancreatic $\beta$-cells," Diabetes, vol. 49, no. 12, pp. 2012-2020, 2000.

[73] C. Cheyssac, C. Dina, F. Leprêtre et al., "EIF4A2 is a positional candidate gene at the 3q27 locus linked to type 2 diabetes in French families," Diabetes, vol. 55, no. 4, pp. 1171-1176, 2006.

[74] R. Meng, C. Götz, and M. Montenarh Mathias, "The role of protein kinase CK2 in the regulation of the insulin production of pancreatic islets," Biochemical and Biophysical Research Communications, vol. 401, no. 2, pp. 203-206, 2010.

[75] K. R. Anderson, P. White, K. H. Kaestner, and L. Sussel, "Identification of known and novel pancreas genes expressed downstream of Nkx2.2 during development," BMC Developmental Biology, vol. 9, no. 1, article 65, 2009.

[76] K. Chu, E. Nemoz-Gaillard, and M. J. Tsai, "BETA2 and pancreatic islet development," Recent Progress in Hormone Research, vol. 56, pp. 23-46, 2001.

[77] L. Zhao, M. Guo, T. A. Matsuoka et al., "The islet $\beta$ cellenriched MafA activator is a key regulator of insulin gene transcription," The Journal of Biological Chemistry, vol. 280, no. 12, pp. 11887-11894, 2005.

[78] M. D. Conkright, G. Canettieri, R. Screaton et al., "TORCs: transducers of regulated CREB activity," Molecular Cell, vol. 12, no. 2, pp. 413-423, 2003.

[79] V. Iourgenko, W. Zhang, C. Mickanin et al., "Identification of a family of cAMP response element-binding protein coactivators by genome-scale functional analysis in mammalian cells," Proceedings of the National Academy of Sciences of the United States of America, vol. 100, no. 21, pp. 12147-12152, 2003.

[80] D. Jansson, A. C. H. Ng, A. Fu, C. Depatie, M. Al Azzabi, and R. A. Screaton, "Glucose controls CREB activity in islet cells via regulated phosphorylation of TORC2," Proceedings of the National Academy of Sciences of the United States of America, vol. 105, no. 29, pp. 10161-10166, 2008.

[81] J. A. Kushner, L. Simpson, L. M. Wartschow et al., "Phosphatase and tensin homolog regulation of islet growth and glucose homeostasis," The Journal of Biological Chemistry, vol. 280, no. 47, pp. 39388-39393, 2005.

[82] L. Wang, Y. Liu, S. Y. Lu et al., "Deletion of Pten in pancreatic $\beta$-cells protects against deficient $\beta$-cell mass and function in mouse models of type 2 diabetes," Diabetes, vol. 59, no. 12, pp. 3117-3126, 2010.

[83] R. Veluthakal, S. V. Madathilparambil, P. McDonald, L. K. Olson, and A. Kowluru, "Regulatory roles for Tiam1, a guanine nucleotide exchange factor for Rac1, in glucosestimulated insulin secretion in pancreatic $\beta$-cells," Biochemical Pharmacology, vol. 77, no. 1, pp. 101-113, 2009.

[84] Y. Cheng and C. Zhang, "MicroRNA-21 in cardiovascular disease," Journal of Cardiovascular Translational Research, vol. 3, no. 3, pp. 251-255, 2010.

[85] S. D. Fenster, M. M. Kessels, B. Qualmann et al., "Interactions between Piccolo and the actin/dynamin-binding protein Abp1 link vesicle endocytosis to presynaptic active zones," The Journal of Biological Chemistry, vol. 278, no. 22, pp. 2026820277, 2003.

[86] D. Nyqvist, S. Speier, R. Rodriguez-Diaz et al., "Donor islet endothelial cells in pancreatic islet revascularization," Diabetes, vol. 60, no. 10, pp. 2571-2577, 2011.

[87] D. Ross Laybutt, H. Kaneto, W. Hasenkamp et al., "Increased expression of antioxidant and antiapoptotic genes in islets that may contribute to $\beta$-cell survival during chronic hyperglycemia," Diabetes, vol. 51, no. 2, pp. 413-423, 2002.

[88] F. Ortis, P. Pirot, N. Naamane et al., "Induction of nuclear factor- $\kappa \mathrm{B}$ and its downstream genes by TNF- $\alpha$ and IL- $1 \beta$ has a pro-apoptotic role in pancreatic beta cells," Diabetologia, vol. 51, no. 7, pp. 1213-1225, 2008.

[89] X. Ma, L. E. Becker Buscaglia, J. R. Barker, and Y. Li, "MicroRNAs in NF- $\kappa$ B signaling," Journal of Molecular Cell Biology, vol. 3, no. 3, pp. 159-166, 2011.

[90] B. Wang, P. Howel, S. Bruheim et al., "Systematic evaluation of three microRNA profiling platforms: microarray, beads array, and quantitative real-time PCR array," PLoS One, vol. 6, no. 2, Article ID e17167, 2011.

[91] Z. Zhang, H. Peng, J. Chen et al., "MicroRNA-21 protects from mesangial cell proliferation induced by diabetic nephropathy in db/db mice," FEBS Letters, vol. 583, no. 12, pp. 2009-2014, 2009.

[92] A. Zampetaki, S. Kiechl, I. Drozdov et al., "Plasma MicroRNA profiling reveals loss of endothelial MiR-126 and other MicroRNAs in type 2 diabetes," Circulation Research, vol. 107, no. 6, pp. 810-817, 2010.

[93] S. D. Jordan, M. Krüger, D. M. Willmes et al., "Obesityinduced overexpression of miRNA-143 inhibits insulinstimulated AKT activation and impairs glucose metabolism," Nature Cell Biology, vol. 13, no. 4, pp. 434-448, 2011.

[94] F. J. Sheedy, E. Palsson-Mcdermott, E. J. Hennessy et al., "Negative regulation of TLR4 via targeting of the proinflammatory tumor suppressor PDCD4 by the microRNA miR-21," Nature Immunology, vol. 11, no. 2, pp. 141-147, 2010.

[95] Y. Cheng, X. Liu, S. Zhang, Y. Lin, J. Yang, and C. Zhang, "MicroRNA-21 protects against the $\mathrm{H} 2 \mathrm{O} 2$-induced injury on cardiac myocytes via its target gene PDCD4," Journal of Molecular and Cellular Cardiology, vol. 47, no. 1, pp. 5-14, 2009.

[96] Y. Cheng, P. Zhu, J. Yang et al., "Ischaemic preconditioningregulated miR-21 protects heart against ischaemia/reperfusion injury via anti-apoptosis through its target PDCD4," Cardiovascular Research, vol. 87, no. 3, pp. 431-439, 2010.

[97] F. Moore, N. Naamane, M. L. Colli et al., "STAT1 is a master regulator of pancreatic $\beta$-cell apoptosis and islet 
inflammation," The Journal of Biological Chemistry, vol. 286, no. 2, pp. 929-941, 2011.

[98] S. A. Sarkar, B. Kutlu, K. Velmurugan et al., "Cytokinemediated induction of anti-apoptotic genes that are linked to nuclear factor kappa-B (NF- $\kappa$ B) signalling in human islets and in a mouse beta cell line," Diabetologia, vol. 52, no. 6, pp. 1092 1101, 2009. 


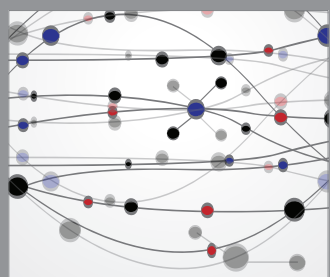

The Scientific World Journal
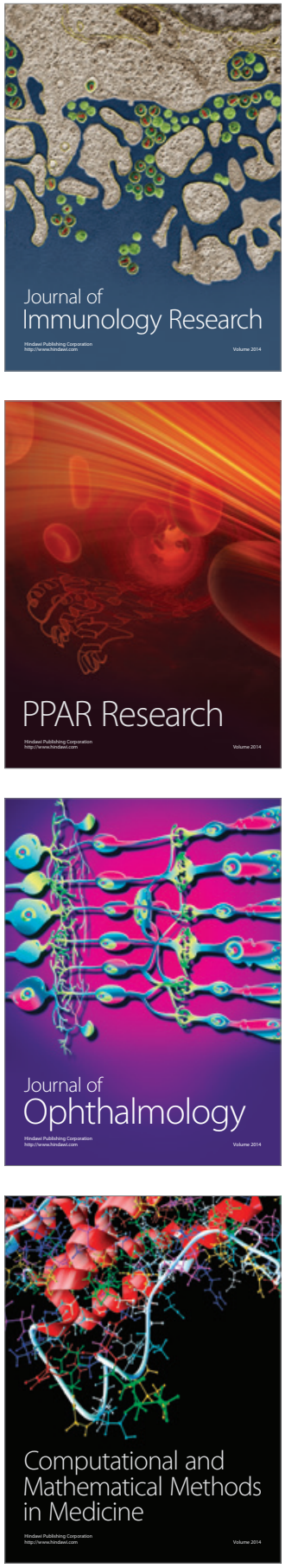

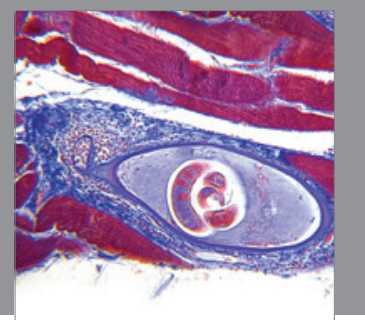

Gastroenterology

Research and Practice
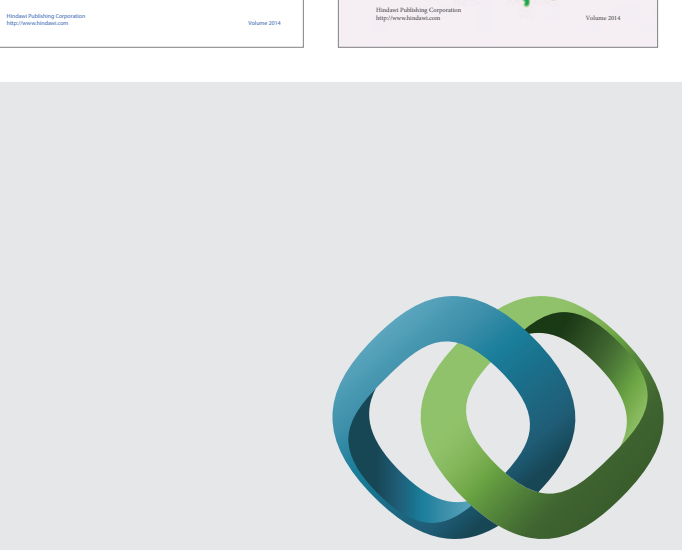

\section{Hindawi}

Submit your manuscripts at

http://www.hindawi.com
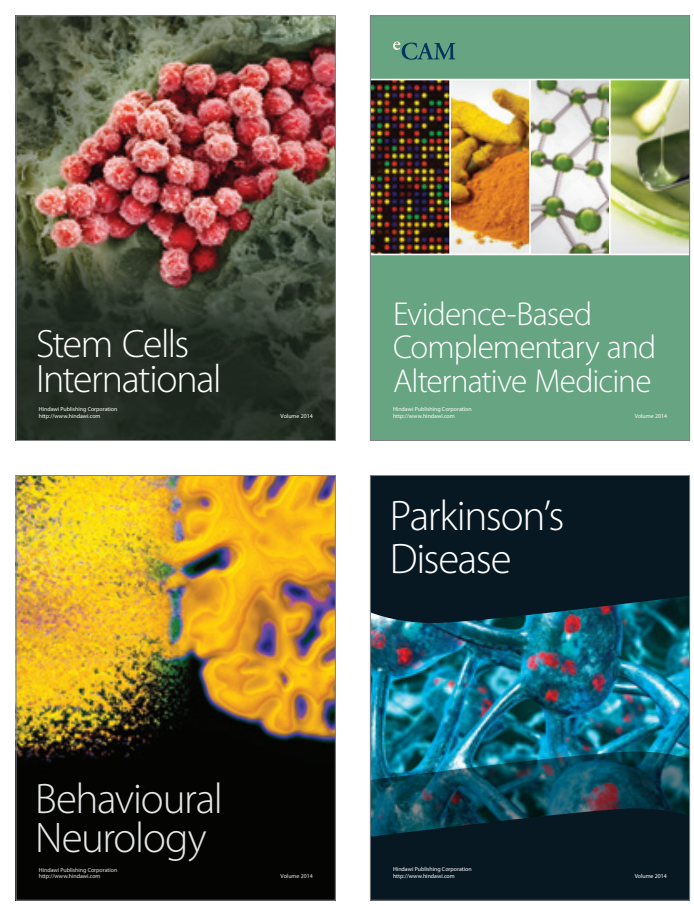

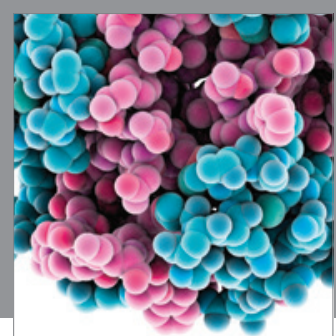

Journal of
Diabetes Research

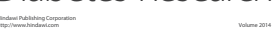

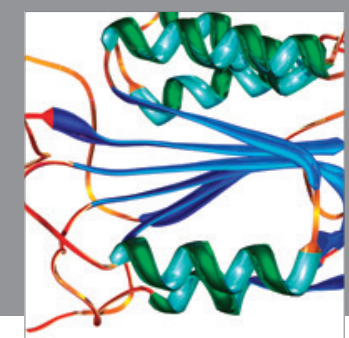

Disease Markers
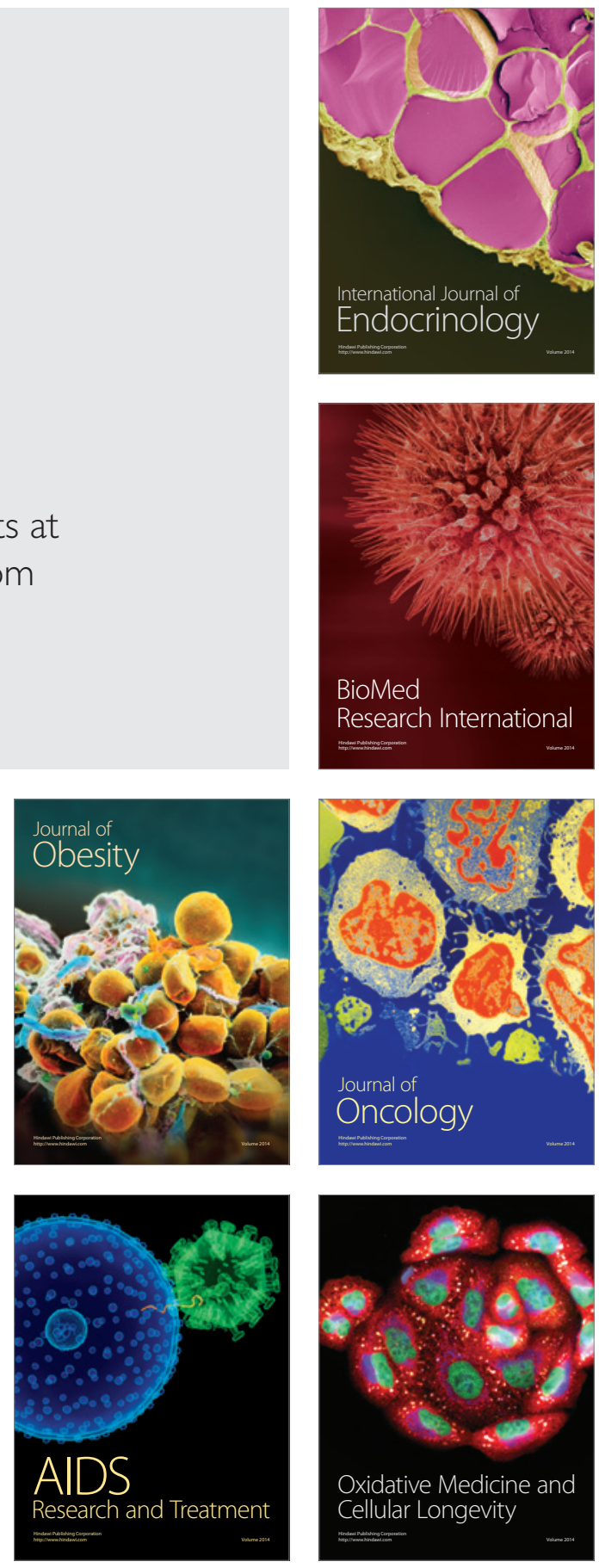